\title{
Keleti import áru a török kori Gyuláról
}

\author{
SZALAI EMESE \\ ELTE BTK Régészettudományi Intézet, Magyar Középkori és Kora Újkori Régészeti Tanszék \\ H-5600 Békéscsaba, Dr. Becsey Oszkár u. 47., szalai.emu@gmail.com
}

Szalai, E.: Oriental import goods from the Ottoman-period Gyula

Abstract: The aim of this paper is to present the most valuable ceramic pieces from the excavations of Gyula Castle (195661), led by Nándor Parádi. It contains the examination of 17 pieces in all, from the groups of Iznik ware, Chinese celadon, porcelain ware and the so-called „Persian" fayance from the 16th-17th centuries.

Keywords: ceramics, 16th-17th centuries, Great Plain of Hungary

\section{A lelöhely}

Gyula városa ma az ország délkeleti határszélén, Békés megyében található. A ma is jelentős alföldi város a Fehér-Körös bal partján jött létre. A középkori mezőváros egyik része Békés vármegye, a másik pedig Zaránd vármegye területén állt, a Békés megyei rész az egri, míg a Zaránd megyei a váradi püspökséghez tartozott. ${ }^{1}$ A vár körül elhelyezkedő település már annak felépülése előtt is létezett: első okleveles említése 1313-ból származik, ekkor Julamonostora-ként olvashatjuk nevét. Az elnevezés eredete az itt álló, Gyula nevű Árpád-kori birtokos által alapított bencés monostorra utal, mely a Váradról Temesvárra vezető út átkelője mellett helyezkedett el. A monostor megszűnte után, de még 1313 előtt a település uradalmi központ lett. Hatalmas méretű uradalma két megyére terjedt ki, és három mezőváros tartozott hozzá: Gyula, Békés és Simánd. ${ }^{2}$ A település a 15. század elején nyerte el a mezővárosi rangot - 1405-ben civitasként, 1419-ben oppidumként szerepel a forrásokban. ${ }^{3}$ Ugyanebben az időben kezdődhetett meg a várépület felépítése is a város területén belül, de a lakónegyedektől elkülönítve, a Fehér-Körös árterének egyik kisebb szigetén. Az építkezést valószínűleg Maróti János macsói bán rendelte el, aki a birtokot 1403-ban Zsigmond király adományaként nyerte el. ${ }^{4}$

A oszmán csapatok 1566-ban hosszú ostrom után, Petrev temesvári pasa vezetésével sikeresen bevették a várat. Az addig határvárként fontos szerepet játszó Gyula ezután is jelentős funkciót töltött be: szandzsákszékhelyként számos katonának, hivatalnoknak és azok családjának adott otthont. ${ }^{5}$ A várban állomásozó katonaságról 1591-ből értesülünk először. Az ekkor készült zsoldösszeírás 609 védő és dzsámialkalmazott nevét tartalmazza, nem szól viszont a tüzérekről, akiket nem készpénzzel, hanem tímárbirtokkal javadalmaztak. Velük együtt a katonaság létszáma 610-620 före tehető. ${ }^{6}$ A rögzített adatok alapján megállapíthatjuk, hogy ekkor Temesvár után Gyula rendelkezett a második legnépesebb őrséggel. A következő ismert zsoldlista keltezetlen, valószínűleg 1621 körül készült. Eszerint ebben az időben 797 katona alkotta az örséget, akik mellett 8 vallási alkalmazott is tevékenykedett a várban. ${ }^{7}$ Ezután már csak az 1628-1630 körüli időszakból ismerünk pontos adatokat, ekkor 890 katona mellett 13 főnyi dzsámialkalmazott alkotta a várbeli személyzetet. ${ }^{8}$ Az elfoglalást követő 129 év során a vár egyszer sem cserélt gazdát, visszafoglalására csak 1695-ben került sor. A 18. század folyamán az épület fokozatosan elveszítette hadászati szerepét, gazdasági célokra alakították át. Használata a következő évszázadban is folyamatos volt, lakottsága pedig csak 1905-ben szűnt meg. ${ }^{9}$

Blazovich 1996. 123

2 Blazovich 2002. 44.

3 Blazovich 2002. 137.

4 A várépület részletes építés- és birtoklástörténetét lásd: Feld 2000., a török korra vonatkozóan pedig: Gerelyes 1989. és Gerelyes 1996.

5 Erre vonatkozóan lásd: Káldy-Nagy 1982. és Hegyi 2007.

6 Hegyi 2007. 1467.

7 Hegyi 2007. 1469.

8 Hegyi 2007. 1475.

9 Parádi 1966. 161. 


\section{Kutatástörténet}

Az Alföld egyetlen viszonylagos épségben fennmaradt vára már a korai időktől kezdve foglalkoztatta a kutatókat. Először Bél Mátyás Békés vármegyéről készült munkájában ${ }^{10}$ olvashatunk róla, majd Karácsonyi János helytörténeti jellegű írásában ${ }^{11}$, és Scherer Ferenc a város történetét feldolgozó művében is helyet kapott. ${ }^{12}$ Ezek a munkák azonban elsősorban az ismert újkori adatokra koncentrálnak, a várépület részletes leírását még nem tartalmazzák. Ugyanez elmondható Varjú Elemér magyar várakról készített összefoglaló múvéről is, melyben a gyulai erősség szintén szerepel. ${ }^{13} \mathrm{~A}$ második világháború után Gerő László foglalkozott több munkájában is Gyulával. ${ }^{14}$ Ezekben tipológiai rendszere alapján a vár feltételezett építéstörténetét is leírja, melyet a későbbi kutatások azonban nem igazoltak. ${ }^{15}$

Tényleges földmunkát csak a második világháború után végeztek az épületben és annak közvetlen környékén. A vár területéröl 1950 körül a 18-19. századi használat során felhalmozódott törmelékes feltöltési rétegek elhordására került sor. Ekkor az udvarról és a földszinti helyiségekből távolították el a földet, az udvar északkeleti részéből pedig a középkori szintet is kitermelték. 1953-54 során Lükő Gábor régész felügyeletével a "rondella" helyreállításával kapcsolatosan annak belsejéből és a vár nyugati oldaláról szintén földet hordtak el ${ }^{16}$ - a munkálatokat egy-egy alkalommal Holl Imre ellenőrizte. A vár déli sarkán álló ötszög alapú tornyot 1954-ben a helyi diákok Kiss István tanár irányításával kiásták, majd visszatemették. ${ }^{17}$ Ilyen előzmények után került sor 1956 és 1961 között a múemléki helyreállítás kapcsán a vár ásatására Parádi Nándor vezetésével. Építéstörténeti eredményeit egy hosszabb tanulmányban ismertette ${ }^{18}$, a leletanyag részletes feldolgozása azonban azóta sem történt meg. A következő értékelés ezt a hiányosságot igyekszik - ha csak részben is - pótolni.

\section{Izniki és kütahyai kerámia}

Ez a kerámiatípus gyártási helyéről, a törökországi Iznikről kapta nevét. A bizánci eredetű települést (Nicaea) az oszmánok az elsők között foglalták el a 13. században ${ }^{19}$, fazekasmühelyek valószínúleg már a 14. század végétől működtek itt. ${ }^{20} \mathrm{~A}$ Gyulán is megtalálható polikróm színvilágú kerámiák az 1520-as években jelentek meg - ez az ún. damaszkuszi stílus. ${ }^{21}$ Ehhez a csoporthoz csupán egy gyulai töredék köthető: a kis tál átfúrt peremén a kék különböző árnyalataival festett stilizált virágminta látható. A halvány árnyalatok alapján ez a darab a klasszikus damaszkuszi stílus (1540-1555) képviselője lehet. Ezt a datálást előkerülési helye, a földszinti 2. helyiség középkori járószintje sem zárja ki, melyről 15. századra keltezhető kopott rézdénár is előkerült (1. tábla 1.). ${ }^{22}$

A 16. század második felétől megszaporodó építkezések az izniki múhelyre is nagy hatást gyakoroltak - innentől az elsődleges árucikk a falicsempe lett. Az új típusú kerámia új technológiát is igényelt, ennek köszönhető a rodoszi típus megszületése. A 16. század végétől a 17. század végéig meghatározó stílust csillogó fehér alapon kobaltkék, zöld, türkiz és piros színek mellett az erőteljes fekete kontúrozás jellemzi. Kedvelt motívuma a szegfü, a tulipán, a rózsa és a jácint kombinálásával létrehozott „négyvirágos stílus”. A korszak nagy technikai újítása a máz alatti piros szín elérése volt - ezt előtte a máz fölé festett, utólag ráégetett technikával állították elő. ${ }^{23} \mathrm{~A}$ rodoszi stílus klasszikus korszakára ez a piros szín egészen tisztává vált, és reliefszerűen kiemelkedett a felületből. ${ }^{24} \mathrm{Az}$ ide sorolható négy gyulai töredék közül három a jellegzetes máz alatti piros szín alapján a rodoszi stílus képviselőjeként határozható meg. Előkerülési helyük a datálás szempontjából nem szolgáltat pontosabb információkat. Két töredéket virágminta, a harmadikat - egy korsó válltöredékét - jellegzetes török arabeszk díszít (1. tábla 2-4.). Az ötödik töredék csillogó fehér alapon kék és türkiz színú mintával van ellátva, lelőhelye ismeretlen. Mintázata nehezen kivehető, talán sárkányt ábrázolhat. Ezt a darabot szintén a rodoszi stílushoz sorolhatjuk a festés színei és az ábrázolt motívum alapján (1. tábla 5.).

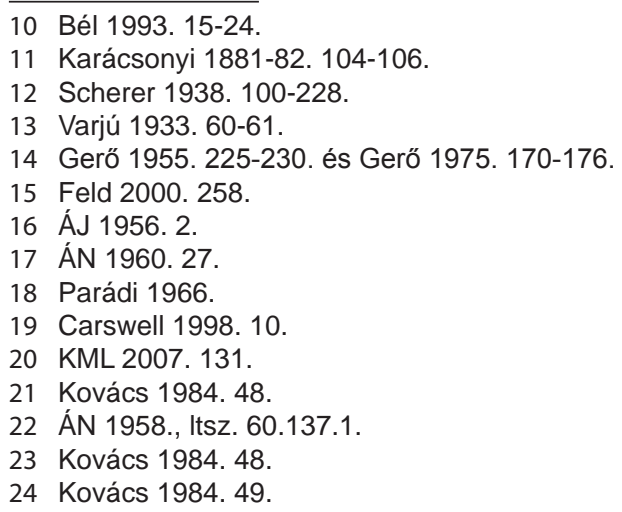


Fontos megjegyezni, hogy a 4. és 5. töredék meghatározása bizonytalan - ezek esetében felmerül a kütahyai készítés lehetősége is. ${ }^{25} \mathrm{~A}$ kütahyai műhelyek felvirágzása az izniki központ hanyatlásával párhuzamosan zajlott a 17. század folyamán. A 18. század elejére Iznikben gyakorlatilag megszűnt az ipari tevékenység, szerepét pedig Kütahya vette át. ${ }^{26}$

Magyarországra a 16. század második felében és a 17. század során érkezett izniki áru. ${ }^{27}$ Budán kívülről csak töredékek ismertek, többek között Szolnokról, Egerből, Pécsről, Barcsról, Esztergomból, Székesfehérvárról, Etéről, Ozoráról, Vácról és Visegrádról. ${ }^{28}$ Viszonylagos ritkaságát az is mutatja, hogy írásos forrásokban sem találkozhatunk vele gyakran. A magyarországi anyagban előforduló edények szinte kivétel nélkül használati tárgyak, melyek helyi igényeket elégítettek ki. A Gyulán előkerült edények 1540 és 1620 között készülhettek, az ismert zárt leletegyüttesek alapján pedig készítésüket követően nem sokkal importálhatták őket. ${ }^{29}$ Az ismert lelőhelyű tárgyak ásatási alaprajzra vetítése során feltűnő volt, hogy ezek a darabok egy területen, a vár délnyugati oldalán elhelyezkedő kapualjban és közvetlen közelében feküdtek. További közös vonásuk, hogy kis mélységből, egyes esetekben közvetlenül a középkori járószint fölötti betöltésből kerültek elő. Legközelebbi párhuzamaik Szolnokról ismertek: itt a legtöbb töredék szintén a rodoszi stílushoz sorolható és csészeként, tálként rekonstruálható. ${ }^{30}$

\section{Szeladon}

Az igen kemény, szürke színű kőcserép Kínában a Sung-korban (960-1279) jelent meg. ${ }^{31}$ A szeladon kifejezés először az Iliászban tűnt fel (egy folyó neveként), majd több görög történetíró is használta ebben a jelentésváltozatban. Ovidiusnál két személy neveként jelent meg: egyikük a Nílus torkolatától, másikuk pedig Thesszalónia hegyeiből származott. A 17. században Ovidiustól vette át a nevet Honoré d'Urfé francia író, aki Astrée című pásztorregényének tapasztalatlan főhősét nevezte el Céladonnak. ${ }^{32}$ A Franciaországban akkoriban megjelenő kínai importárut köpenyének halványzöld színe után kezdték szeladonnak hívni. ${ }^{33}$ Készítési technikája a következőképpen írható le: az edényt megformálása után vasoxid-tartalmú mázzal látták el, majd magas hőmérsékleten, oxigénmentes környezetben égették ki. A redukciós égetés következtében az agyag színe szürke, a mázé pedig halvány szürkészöld lett. A máz alatt az edény felületét gyakran bekarcolt, bemélyített, vagy reliefszerűen kiemelkedő díszítéssel látták el, de formába préselt, utólag hozzáillesztett díszítményekkel is találkozhatunk. ${ }^{34}$

A gyulai anyagban három edény töredékei találhatóak meg. Ezek közül a legjelentősebb az a teljes egészében rekonstruálható edény, mely jelenleg a Magyar Nemzeti Múzeum állandó kiállításában látható. ${ }^{35}$ A kissé lapított, virágkehelyre emlékeztető formájú folyadéktároló edény mindkét oldalán azonos minta szerepel: középen kínai írásjegy látható, ezt virágmotívum veszi körbe, az edény nyakán nehezen kivehető, talán szintén növényi jellegű motívum fölött pedig felhőszerű mintázat található. A díszítmény központi részén elhelyezkedő írásjel a kínai fu-val azonosítható, mely szerencsét, gazdagságot jelent (2. tábla 1.). ${ }^{36}$ Legközelebbi formai párhuzama egy 12-13. századi edény, mely egy észak-kínai pagoda kincstárából került elő. ${ }^{37}$ Itt kell még megjegyeznem, hogy ugyanezzel a leltári számmal található az anyagban egy kis méretű, szögletes fül töredéke is. ${ }^{38} \mathrm{~A}$ második edényből csupán az alj maradt meg, melyen körben bordás díszítés fut (2. tábla 2.). Hasonló díszítéssel rendelkezik a budai várban feltárt szeladon kancsó, mely díszítése mellett talán az edény egykori funkciója szempontjából is analógiának tekinthető. ${ }^{39}$ A leltári számok alapján ugyanezen edényhez tartozik a harmadik darab is, egy faltöredék. Ez azonban a többitől eltérően fehér mázzal borított, így véleményem szerint nem tartozhat össze az aljtöredékkel. A megszokottól eltérő mázszínre mindeddig nem találtam magyarázatot. A máz miatt ez a darab csak feltételesen sorolható a szeladonok közé, annak ellenére, hogy anyagában látszólag megegyezik azokkal (2. tábla 3.).

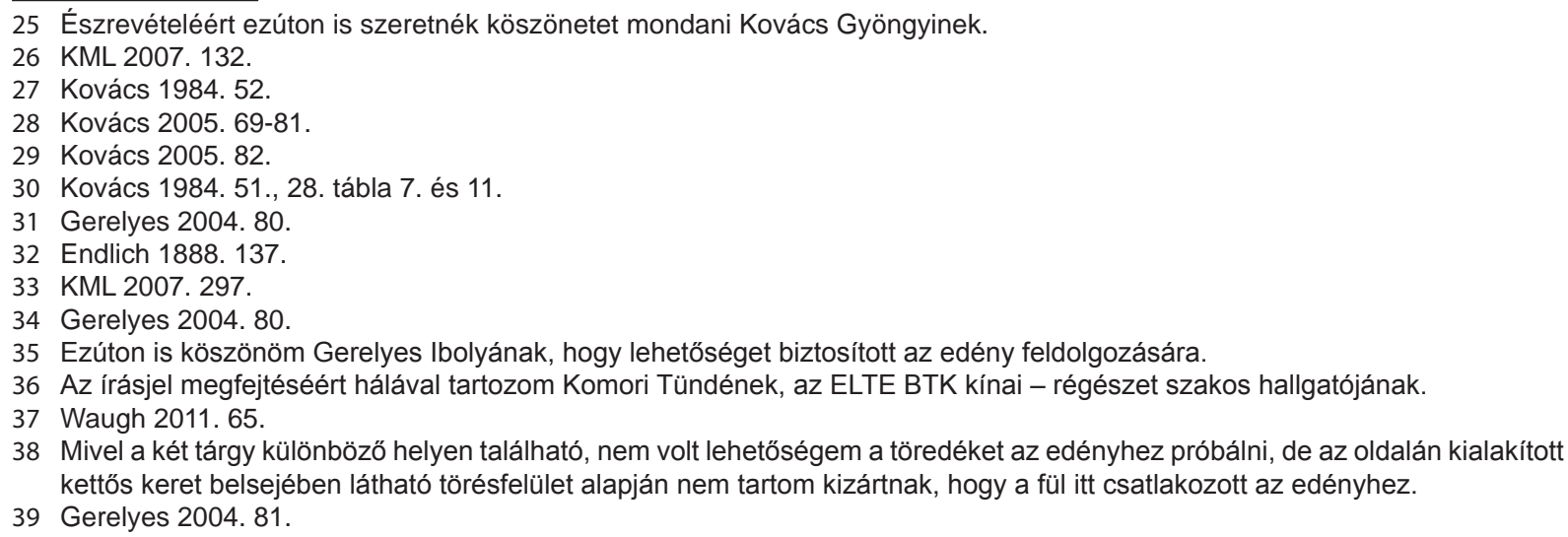

38 Mivel a két tárgy különböző helyen található, nem volt lehetőségem a töredéket az edényhez próbálni, de az oldalán kialakított kettős keret belsejében látható törésfelület alapján nem tartom kizártnak, hogy a fül itt csatlakozott az edényhez.

39 Gerelyes 2004. 81. 
Magyarországról csak nagyon kis mennyiségben ismerünk szeladon árut; Budáról két hullámos peremú tál, egy tányér és egy kancsó a palota ásatásai során került felszínre. Ezekkel a 15. század végére - a 16. század első felére keltezhető darabokkal kapcsolatban felmerült a lehetőség, hogy már a 15. század végén - az oszmán hódítás előtt - megjelentek a királyi udvarban ${ }^{40}$ Budán kívül Egerből ismert egy tál töredéke, korai 18. századi leletekkel kevert rétegből, illetve Szekszárd-Újpalánkról utánzatának néhány darabja. A török forrásokban mertebanî néven említett edények importja az Oszmán Birodalomba a porcelánnal együtt, 1550 körül lendült fel, és egészen a 17. század első feléig számolhatunk vele. ${ }^{41}$ A szeladon áru a késői összeírásokban tűnik még fel, ezek az említések egybeesnek folyamatos importálásukkal a 17. század első felében. ${ }^{42}$ Mivel a kínai múhelyek akár több száz évig is használhattak egy-egy formai megoldást, az edények stilisztikai alapon pontosabban nem keltezhetőek. Sajnos a probléma megoldásában előkerülési helyük sem segít, mivel mindhárom gyulai töredék kevert rétegből származik.

\section{Kínai porcelán}

Porcelánnak a kaolin, kvarc és földpát keverékéből álló, magas hőfokon kiégetett, fehér színű, fényáteresztő, ütésre csengő hangot adó kerámiát nevezzük. ${ }^{43}$ Legjellegzetesebb csoportjuk a kék festésú kerámia, de előfordul kívül zöld vagy barna színú, tiszta fehér és színes, emailos festésű darab is. ${ }^{44} \mathrm{~A}$ porcelánok mintakincse szimbolikus jelentéssel bírt: a barack például az örök élet gyümölcse volt, a gomba jókívánságot közvetített, a tájkép pedig az alapelemekre utalt - az exportra készülő darabok mintái azonban a vásárlók számára valószínúleg csak dekorációs elemek lehettek. ${ }^{45}$

Gyuláról öt töredékük ismert, ezek mind a kék-fehér csoportba sorolhatóak, és csészékhez tartoztak. Az első kis mérete miatt nehezen vizsgálható, annyi azonban megállapítható, hogy mintázatát függőleges és vízszintes vonalakkal osztott mezőkben helyezték el. Ez a fajta szerkesztésmód 1575-85 körül jelent meg, és később is alkalmazták. A hangsúlyozott keretelés alapján ez az edény már a 17. század elején készülhetett (3. tábla 1.). Hasonló darab a budai vár ásatásaiból ismert. ${ }^{46} \mathrm{~A}$ következő két töredék mérete már jóval nagyobb. Az egyik mintázatának csak a széle látszódik, budai párhuzamai alapján azonban feltételezhetjük, hogy ezt is a szerencsét hozó gomba motívuma díszíthette (3. tábla 2.). ${ }^{47} \mathrm{~A}$ másik darab peremén futó vízszintes vonalak alatt talán stilizált virágminta látható (3. tábla 3.). Hasonló került elő a budai palota 31. gödréből, mely a 17. század első harmadában került szemétbe. ${ }^{48} \mathrm{~A}$ leginkább beazonosítható mintázattal egy kis csésze peremtöredéke rendelkezik. Ennek külső oldalát az egész felületet betöltő leveles indák díszítik (3. tábla 4.). Ez a motívum a kínai porcelánokon igen kedvelt, több hasonló darabot is ismerünk a magyarországi anyagból: legközelebbi párhuzama Szolnokon került elő, ez azonban a gyulaitól eltérően polikróm festésű. ${ }^{49}$ Ugyanez a mintázat figyelhető meg továbbá az egri anyag két töredékén, ${ }^{50}$ két bajai példányon ${ }^{51}$ és két budai csészén is ${ }^{52}$, valamint egy további töredéken a Vizivárosból. ${ }^{53} \mathrm{Az}$ utolsó edény fenéktöredékének belső oldalán gyümölcsös faág ábrázolásának részlete látszódik (3. tábla 5.). Nagyon hasonló csésze ismert a budai palota egyik pincéjéből ${ }^{54}$ és a domonkos kolostorból ${ }^{55}$, de a perzsa fajanszárukon is kedvelt motívum. ${ }^{56}$

Magyarországon már a 14. század második felében is találkozhatunk ezzel az áruval - a budai leletek alapján Nagy Lajos király udvarában már ekkor használatban volt néhány darab. ${ }^{57}$ Nagyobb mennyiségben a törökökkel érkezett az országba a 16-17. század folyamán. A töredékek legnagyobb része kis csészéhez tartozhatott, és a Ming-korban (1368-1644) készülhetett. Keltezésüket nehezíti, hogy a töredékes darabokon amúgy is nehezen kivehető minták akár évszázadokig is élhettek. ${ }^{58}$ Szerencsés esetben a fenéken

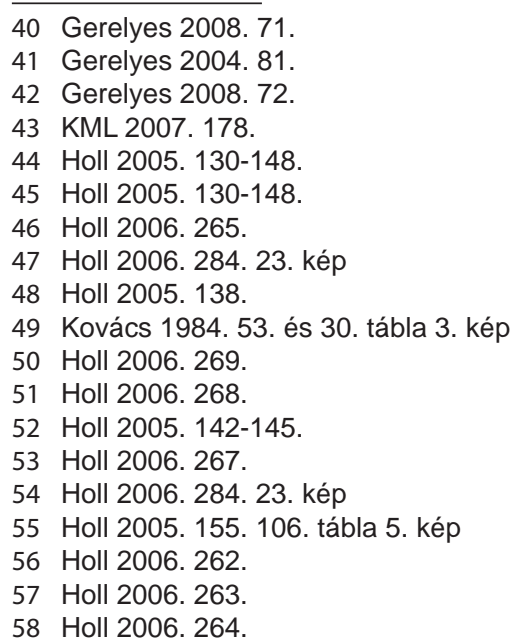


elhelyezett hitelesítő császárjegy támpontot adhat a készítés idejének meghatározásához ${ }^{59}$, ez azonban az olcsóbb darabokról hiányzik ${ }^{60}$, és sajnos a gyulai darabok esetében sem vizsgálható. Összességében annyit állapíthatunk meg biztosan, hogy a Gyulán előkerült darabok a 16. század végétől a 17. század első feléig datálhatóak.

\section{Perzsa fajansz}

A kínai porcelánedények másolataként kialakult kerámiatípus jellemzője a fehér agyagból készülő, viszonylag vékony fal és a máz alatti kobaltkék festés. A kék színt helyi eredetű festékanyaggal érték el, így színe némiképp eltér az eredeti darabokétól. ${ }^{61} \mathrm{~A}$ kínai minták vörös és barna színét nem tudták előállítani, ezért a fehér anyagot ún. bólusz-vörös színű földfestékkel vonták be, majd az edény színtelen mázat kapott, és így égették ki még egyszer. A rosszabb minőségú edények esetében a felületen irizáló réteg alakult ki. ${ }^{62}$ Motívumkincsük az eredeti kínai minták utánzásával jött létre, aljukon hitelesítő jegy helyett gyakran szerepel valamilyen elnagyolt folt vagy geometrikus minta. ${ }^{63} \mathrm{Ez}$ a típus a mindennapi használatban nagyon elterjedt volt, elsősorban tea, kávé vagy bor fogyasztására szolgált. A legújabb kutatások szerint nem zárható ki, hogy kínai mintára készülő kávéscsészék Iznikben is készültek - ez magyarázatot adna magyarországi megjelenésükre is. ${ }^{64}$

Gyulán négy edény töredékei kerültek elő, az összes csészéhez tartozó darab. A legjelentősebb egy nagyobb méretű aljtöredék, melyet kívül piros foltok és a talpkarimán futó kék vonalak, belül piros színú rozetta és kék csík díszít. Az edény igen rossz megtartású, puha fajanszból készülhetett - erre utal sárga színe is (4. tábla 1.). Az edény egy ritka 15. századi kínai típus 17. századi utánzata lehet. ${ }^{65}$ Szinte tökéletes párhuzama került elő H. Gyürky Katalin ásatásaiból a budai Táncsics Mihály u. 7. szám alól ${ }^{66}$, de hasonló darab a palotából is ismert. ${ }^{67}$ Egy kisebb csésze aljtöredékét belül virágmotívum díszíti, külső oldalán kínai császárjegyet imitáló geometrikus minta látható. Anyaga az előzőhöz képest jobb minőségű, keményebb fajansz (4. tábla 2.). Ugyanilyen mintázatú töredék ismert Egerből - a két darabon még a hitelesítő jegyet imitáló minta is megegyezik. ${ }^{68} \mathrm{~A}$ harmadik aljtöredék felületét erősen irizáló réteg fedi. Belső oldala díszítetlen, külsején kék festésű, kivehetetlen (talán növényi?) motívum látható. Anyaga az előzőhöz hasonlóan kemény fajansz (4. tábla 3.). Az utolsó darab kívül piros színú kínai csoportot utánzó csésze, belső oldalán kék festéssel (4. tábla 4.). Ehhez a csoporthoz tartozó leletek kerültek elő a budai palota feltárása során is. ${ }^{69}$

A perzsa csészék Budára már a török kor előtt eljutottak, de szélesebb körben a hódoltság időszakában terjedtek el. ${ }^{70} \mathrm{Az}$ eddigi kutatások alapján a 17. században a kínai porcelánok mellett igen gyakori árucikknek számítottak. Az írásos forrásokban a 17. század elején megjelenő findzsa megnevezés nem csak a porcelánra, hanem perzsa árura is vonatkozhat, időnként pedig a forrás kifejezetten különbséget tesz findzsa és porcelán között. ${ }^{71}$ Keltezésük a török koron belül igen nehézkes - ezt egyrészt az anyag alacsony feldolgozottsági szintje okozza, másrészt pedig a tárgyak jellege. Ha fel is ismerhető a kínai előkép, nem tudjuk, hogy a másolás menynyivel később történt meg. ${ }^{72}$ Mivel a gyulai perzsa darabok kevert rétegből, illetve szórványként kerültek elö, ezek datálása sem pontosítható a 17. századon belül.

\section{Összegzés}

A luxuscikknek számító import áru megjelenése Gyula szandzsákközpontként betöltött kiemelkedő szerepét jelzi. Az előkerült darabok jól illeszkednek a kutatások során eddig kialakult képbe: a 16. század második felének luxus árucikke az izniki fajansz, majd ezt a 17. században egyre inkább kiszorítja a kínai porcelán és ennek perzsa utánzata. Feltűnő, hogy a teljes anyagmennyiséghez képest (összesen 181 edény töredékei köthetőek egyértelmủen a törökökhöz) Gyulán csak igen kis mennyiségben került elő külföldi importáru, míg a közeli Szolnok és Szeged esetében ez az arány jóval nagyobb.

59 Kovács 1984. 53.

60 Holl 2006. 262.

61 Hancz 2006. 35.

62 Hancz 2006. 34.

63 Hancz 2006. 35.

64 Gerelyes 2008. 69.

65 Holl 2006. 263.

66 Holl 2006. 266.

67 Holl 2006. 263.

68 Holl 2006. 268.

69 Holl 2006. 263.

70 Holl 2006. 260.

71 Gerelyes 2008. 69

72 Holl 2006. 262. 
A tárgytípusokat vizsgálva megállapíthatjuk, hogy a legtöbb töredék kis tálhoz, csészéhez tartozik - ez az edénytípus a kávé- és teafogyasztás szokásához köthető. A kávé fogyasztása a 16. század közepétől általános volt, az italt kardamommal és ámbrával ízesítettek. A kávézás és az ezt kísérő pipázás a férfiak és a nők körében is megszokott volt. ${ }^{73} \mathrm{~A}$ különleges élvezeti cikk Magyarország területére is hamar eljutott: a vámjegyzékek szerint Budára már 1579-ben szállították. ${ }^{74}$

Az eddigi kutatások eredményei alapján, melyek elsősorban az írott forrásokra támaszkodtak, a belső várat a török korban - legalábbis annak a 17. század második felére eső időszakában - nem használták. ${ }^{75} \mathrm{Az}$ ismert lelőhelyű tárgyak térképre vetítése során azonban megfigyelhető, hogy a leletek az épületen kívül, vagy a bejárat közvetlen közelében feküdtek (a leletek hiányának magyarázata az épületen belül talán a vár folyamatos 17-18. századi használatában keresendő) (5. tábla). Ez alapján tehát úgy tűnik, hogy valamikor az időszak folyamán az épület lakott lehetett, sőt, figyelembe véve a tárgyak luxus jellegét, éppen a katonaság vezető rétegének adhatott szállást. Ezt az elméletet alátámasztani látszik az a tény, hogy a külső várban végzett ásatások során import darabok nem kerültek elő ${ }^{76}$, illetve Evlia Cselebi leírása, mely szerint: „E belső várban csak a parancsnok aga lakik...". ${ }^{77} \mathrm{~A}$ fent felvetett gondolatot igazolni vagy cáfolni természetesen csak a külső vár területén végzett újabb feltárások segítségével lehetne.

\section{Oriental import gods from the Ottoman-period Gyula}

\section{EMESE SZALAI}

The town of Gyula, which now can be found near the south-eastern border of Hungary, was mentioned first in 1313 as a settlement with a benedict monastery nearby. Later, in the 15th century, it became a country town and the center of an enormous property. Most likely this was the period when the construction works of the castle begun, after the donation of the whole property to János Maróti by king Sigismund. The castle was occupied by ottoman armies in 1566 and remain under their governance until 1695. After the town was taken back by the Habsburgs, the castle was used to economical causes, and was inhabited until 1905. After some smaller works in the 1950's, the first excavation was carried out between 1956 and 1960, but the findings were not interpreted until now.

Iznik fayance ware is represented by 5 pieces in Gyula. One of them can be identified as a representative of the group called "classical Damaskus ware", based upon its finding place and its colors. The group dates from 1540 to 1555.3 of the other 4 pieces are easily listed to the group of "Rodos ware" (from the end of the 16th century to the end of the 17th century) based on the red color used on them, and most probably the last one belongs here as well. All of them laid nearby the south-western gate, right above the medieval layers. There are 3 pieces of Chinese celadon ware among the pottery, the most remarkable is the one that could be completed during the restoration. It is decorated with typical Chinese floral motives and the mark "fu", meaning fortune and wealth. The second one is the lower part of a vessel with ribbed decoration around the bottom. A jug from Buda has the same decoration and maybe the same function as well. The last piece is a fragment with white glaze. All of them came to light from mixed layers, therefore can not be dated more precisely. The 4 fragments of porcelain cups have typical Chinese painted motives. The first one is framed by multiple lines - this style evolved between 1575 and 1585 and was also used later -, and was made in the first half of the 17th century. On the other pieces we can find mushrooms (they brig luck), floral motives and a branch with peaches. In lack of any authenticator marks on the bottom, they can be dated from the end of the 16th century to the first half of the 17th century. The last group is the one of Persian fayance, which contains 4 pieces. The first is a replication of a 15th century porcelain type, made in the 17th century. The others were made in the same period. All of them were small cups for tea or coffee.

If we compare the proportion of imported pottery in Gyula and in nearby castles, we can see that it is much smaller here than in Szolnok or Szeged. This phenomenon can be explained by the contiguous use of the building in the 18th-19th centuries. The function of the building in ottoman times can be defined based on the spred of the pottery analyzed above: probably it was the accommodation of military leaders.

\footnotetext{
73 Yerasimos 2007. 38.

74 Holl 2005. 160.

75 Gerelyes 1996. 112.

76 Gerelyes 1996. 120-122.

77 Karácson 1908. 227.
} 


\section{Irodalom}

ÁJ: ásatási jelentés

ÁN: ásatási napló

Bél M. 1993.: Békés vármegye leírása. Gyula

Blazovich L. 1996.: Blazovich László (szerk.): A Körös-Tisza-Maros-köz települései a középkorban. Dél-Alföldi Évszázadok 9. Szeged

Blazovich L. 2002.: Városok az Alföldön a 14-16. században. Dél-Alföldi Évszázadok 17. Szeged

Carswell, J. 1998.: Iznik Pottery. London

Endlich, F. M. 1888.: On Some Interesting Derivations of Mineral Names (Continued). The American Naturalist 22/254. 128142.

Feld I. 2000:: A gyulai vár a középkorban. In.: Kollár Tibor - Bardoly István - Lővei Pál (szerk.): A középkori Dél-Alföld és Szer. Dél-Alföldi Évszázadok 13. Szeged, 257-280.

Gerelyes I. 1989.: A gyulai külső vár a visszafoglalás korában és a 17-18. század fordulóján. In.: Végvár és társadalom a viszszafoglaló háborúk korában. Studia Agriensia 9. Eger, 127-141.

Gerelyes I. 1996:: Török építkezések Gyulán. In: Szatmári Imre - Gerelyes Ibolya: Tanulmányok a gyulai vár és uradalma történetéhez. Gyulai Füzetek 8. Gyula, 88-129.

Gerelyes I. 2004.: Kínai szeladon kerámia a budavári palota leletanyagában. Budapest Régiségei 38. 79-91.

Gerelyes I. 2008.: Types of Oriental Pottery in Archaeological Finds from the 16th and 17th centuries in Hungary. Acta Orientalia 61/1-2. 65-76.

Gerő L. 1955.: Magyarországi várépítészet. Budapest

Gerő L. 1975.: Várépítészetünk. Budapest

Hancz E. 2006.: A szegedi vár kerámiaanyaga a török korban. Castrum 4. 31-46.

Hegyi K. 2007:: A török hódoltság várai és várkatonasága 3. A temesvári, győri, pápai, egri, kanizsai, váradi és újvári vilájet várainak adattára. História Könyvtár - Kronológiák, adattárak 9. Budapest

Holl I. 2005.: Fundkomplexe des 15-17. Jahrhunderts aus dem Burgpalast von Buda. Varia Archaeologica Hungarica 17. Budapest

Holl I. 2006.: Külföldi kerámia Magyarországon III. (14-17. század). Budapest Régiségei 40. 253-294.

Káldy-Nagy Gy. 1982.: A gyulai szandzsák 1567. és 1579. évi összeírása. Forráskiadványok a Békés megyei levéltárból 10. Békéscsaba

Karácson I. 1908.: Evlia Cselebi török világutazó magyarországi utazásai 1664-1666. Budapest

Karácsonyi J. 1881-82.: Gyulának, a gyulai uradalomnak és a gyulai várnak keletkezése. In.: Békésvármegyei Régészeti és Müvelödéstörténelmi Társulat Évkönyve 8. Gyula

KML 2007.: Fajcsák Gyöngyi (Szerk.): Keleti Múvészeti Lexikon. Budapest

Parádi N. 1966:: A gyulai vár ásatásának építéstörténeti eredményei. Magyar Müemlékvédelem 3. 135-166.

Kovács Gy. 1984.: Török kerámia Szolnokon. Szolnok megyei Múzeumi adattár 30-31. Szolnok

Kovács Gy. 2005.: Iznik Pottery in Hungarian Archaeological Research. In.: Gerelyes Ibolya (ed.): „Turkish Flowers". Studies on Ottoman Art in Hungary. Budapest, 69-96.

Scherer F. 1938.: Gyula város története I. Gyula (reprint, 1989.)

Varjú E. 1933.: Magyar várak. Budapest

Waugh, D. C. 2011.: The Chaoyang Northern Pagoda. A Photo Essay. The Silk Road 9. 53-70.

Yerasimos, M. 2007.: 500 years of Ottoman Cuisine. Istanbul 


\begin{tabular}{|c|c|c|c|c|c|c|c|c|c|c|c|c|c|c|c|c|c|}
\hline 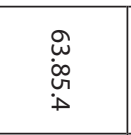 & 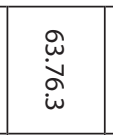 & $\begin{array}{l}\stackrel{0}{\omega} \\
\text { in } \\
\stackrel{\vec{v}}{v}\end{array}$ & 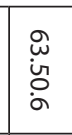 & $\begin{array}{l}\stackrel{9}{u} \\
\dot{u} \\
\underline{\omega} \\
\underline{G}\end{array}$ & 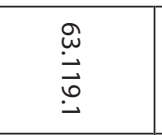 & $\begin{array}{l}8 \overrightarrow{0} \\
\dot{\vec{v}} \\
\text { ूn }\end{array}$ & $\underset{\substack{\vec{\omega} \\
\dot{\omega} \\
\dot{D}}}{ }$ & 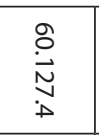 & $\underset{\stackrel{O}{\dot{N}}}{\stackrel{\tilde{N}}{\mathrm{~N}}}$ & $\begin{array}{l}u \\
0 \\
0 \\
\dot{0} \\
ن\end{array}$ & $\begin{array}{l}\text { Un } \\
\stackrel{D}{ } \\
\text { in } \\
\frac{N}{N}\end{array}$ & $\begin{array}{l}\text { Un } \\
\dot{D} \\
\text { in } \\
\stackrel{N}{\Delta}\end{array}$ & $\begin{array}{l}\text { Uू } \\
\stackrel{\vec{\omega}}{\omega}\end{array}$ & $\begin{array}{l}\stackrel{u}{0} \\
\stackrel{\vec{\sim}}{u}\end{array}$ & 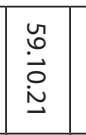 & $\begin{array}{l}U_{0} \\
\stackrel{0}{0}\end{array}$ & 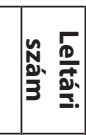 \\
\hline 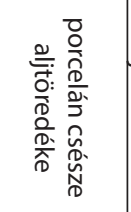 & 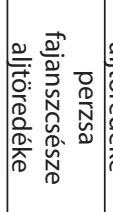 & 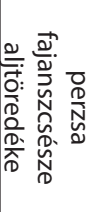 & 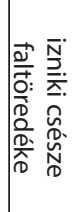 & 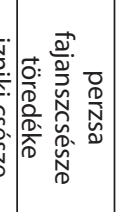 & 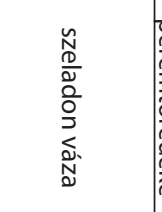 & 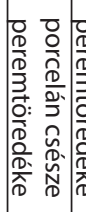 & 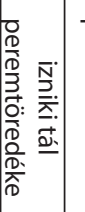 & 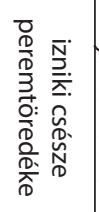 & 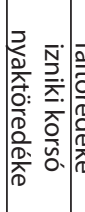 & 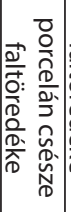 & 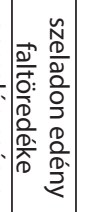 & 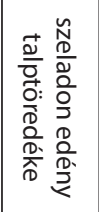 & 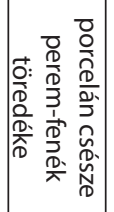 & 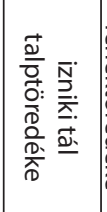 & 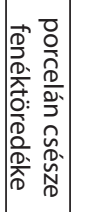 & 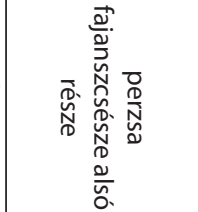 & $\begin{array}{l}3 \\
3 \\
0 \\
0 \\
0 \\
0 \\
0 \\
0 \\
0 . \\
0 .\end{array}$ \\
\hline 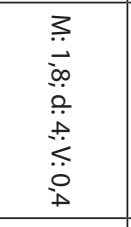 & 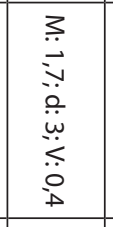 & $\begin{array}{l}3 \\
\stackrel{N}{N} \\
\stackrel{N}{0} \\
\stackrel{\leftrightarrow}{\dot{N}} \\
\text { N }\end{array}$ & 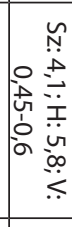 & 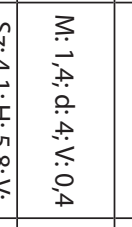 & 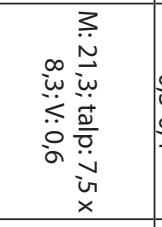 & 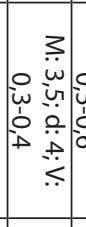 & 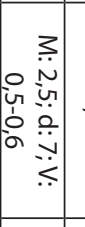 & 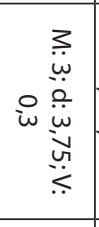 & 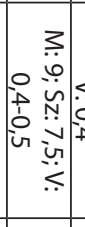 & 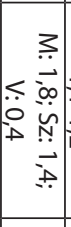 & 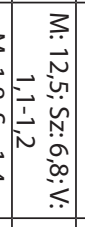 & 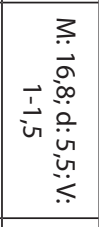 & 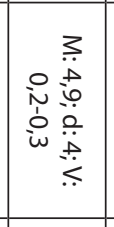 & 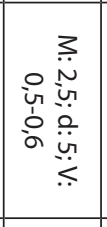 & 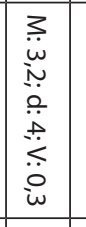 & 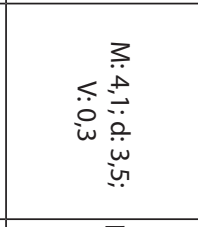 & 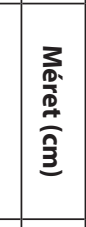 \\
\hline $\begin{array}{l}\frac{\vec{p}}{\vec{D}} \\
\stackrel{\vec{D}}{=}\end{array}$ & $\frac{\overrightarrow{\underline{D}}}{\vec{D}}$ & $\begin{array}{l}\frac{\vec{p}}{\vec{D}} \\
\stackrel{\vec{D}}{\sim}\end{array}$ & 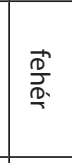 & $\frac{\vec{D}}{\stackrel{\vec{D}}{\underline{D}}}$ & 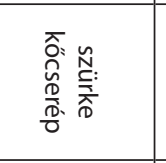 & $\frac{\vec{\Phi}}{\vec{D}}$ & 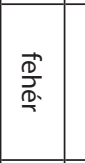 & $\frac{\vec{p}}{\stackrel{\vec{D}}{\underline{D}}}$ & $\frac{\vec{D}}{\vec{D}}$ & $\begin{array}{l}\vec{D} \\
\stackrel{D}{\vec{D}} \\
\end{array}$ & 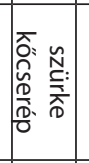 & 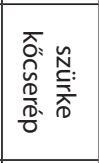 & $\frac{\vec{D}}{\vec{D}}$ & 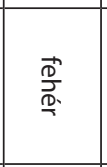 & $\frac{\vec{D}}{\stackrel{\vec{D}}{\sim}}$ & 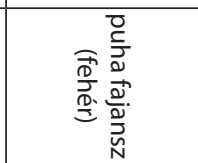 & 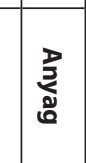 \\
\hline $\begin{array}{l}\overline{0} \\
\frac{0}{O} \\
\stackrel{0}{0} \\
\stackrel{\circ}{\rightleftharpoons}\end{array}$ & 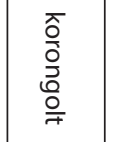 & $\begin{array}{l}\overline{\widehat{O}} \\
\frac{0}{0} \\
\frac{0}{0} \\
\frac{0}{7}\end{array}$ & $\begin{array}{l}\bar{T} \\
\frac{0}{O} \\
\frac{O}{0} \\
\frac{0}{\mp}\end{array}$ & $\begin{array}{l}\overline{\widehat{O}} \\
\frac{0}{0} \\
\frac{0}{0} \\
\frac{O}{7}\end{array}$ & 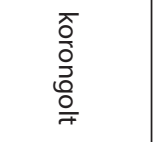 & 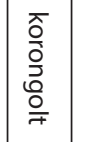 & 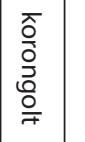 & 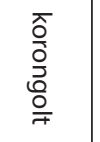 & $\begin{array}{l}\overline{\widehat{O}} \\
\frac{0}{O} \\
\overline{0} \\
\stackrel{\circ}{\mp}\end{array}$ & 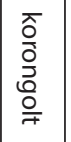 & $\begin{array}{l}\overline{\widehat{O}} \\
\frac{0}{0} \\
\frac{0}{\circ} \\
\frac{0}{7}\end{array}$ & $\begin{array}{l}\overline{\widehat{O}} \\
\frac{0}{0} \\
\frac{0}{0} \\
\frac{O}{7}\end{array}$ & $\begin{array}{l}\overline{\widehat{O}} \\
\frac{0}{0} \\
\frac{0}{0} \\
\frac{0}{7}\end{array}$ & 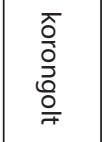 & 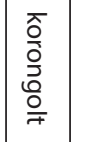 & $\begin{array}{l}\overline{\widehat{O}} \\
\frac{0}{0} \\
\frac{0}{0} \\
\frac{O}{7}\end{array}$ & 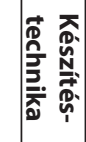 \\
\hline 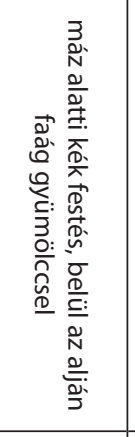 & 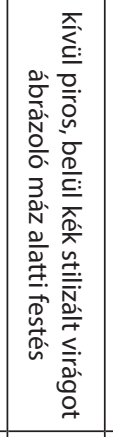 & 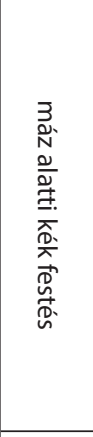 & 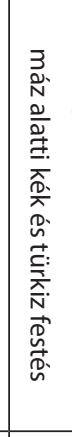 & 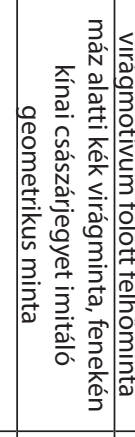 & 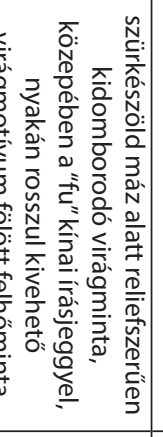 & 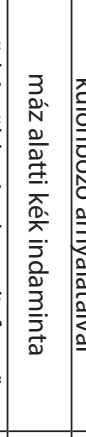 & 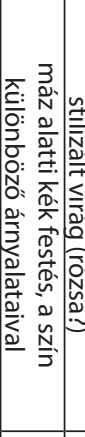 & 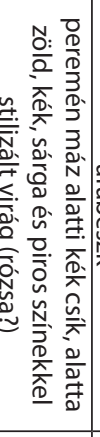 & 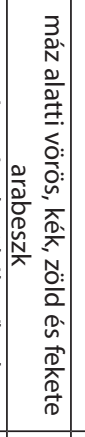 & 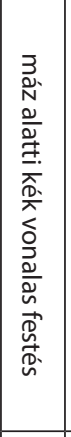 & 疍. & 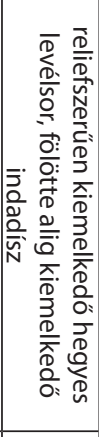 & 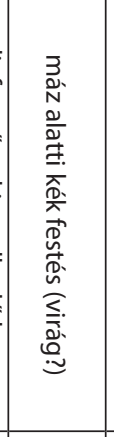 & 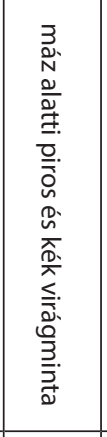 & 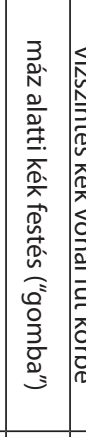 & 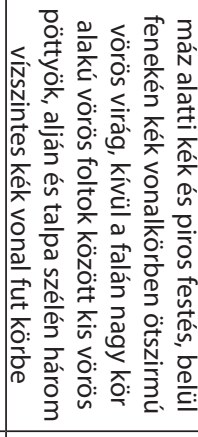 & 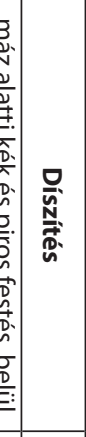 \\
\hline $\begin{array}{l}\stackrel{\tilde{N}}{=} \\
\stackrel{\vec{N}}{\mathbb{N}} \\
\frac{D}{2}\end{array}$ & 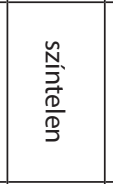 & 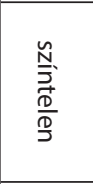 & 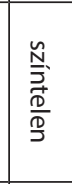 & $\begin{array}{l}\frac{N}{\tilde{N}} \\
\frac{\vec{D}}{D} \\
\frac{D}{D}\end{array}$ & 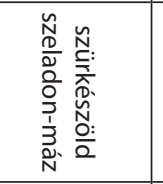 & 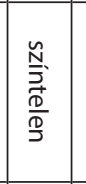 & $\begin{array}{l}\tilde{N} \\
\stackrel{N}{=} \\
\frac{D}{D} \\
\frac{D}{2}\end{array}$ & $\begin{array}{l}\stackrel{\mathscr{N}}{=} \\
\stackrel{\vec{D}}{D} \\
\frac{D}{D} \\
\frac{D}{D}\end{array}$ & $\begin{array}{l}\frac{N}{N} \\
\stackrel{\vec{E}}{\vec{D}} \\
\frac{D}{D} \\
\frac{D}{D}\end{array}$ & 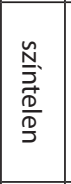 & $\frac{\vec{\Phi}}{\overrightarrow{\underline{D}}}$ & 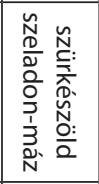 & $\begin{array}{l}\frac{\tilde{N}}{\bar{N}} \\
\frac{\vec{D}}{\mathcal{D}} \\
\frac{D}{2}\end{array}$ & $\begin{array}{l}\frac{\mathscr{N}}{\vec{J}} \\
\frac{\vec{D}}{D} \\
\frac{D}{D}\end{array}$ & 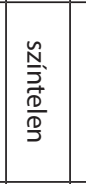 & $\begin{array}{l}\stackrel{\mathscr{N}}{\vec{J}} \\
\frac{D}{D} \\
\frac{D}{D}\end{array}$ & 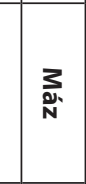 \\
\hline- & - & - & - & - & $\stackrel{\check{o}}{\lambda}$ & - & - & $N$ & - & - & - & $A$ & - & - & - & $\vec{\omega}$ & 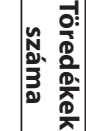 \\
\hline 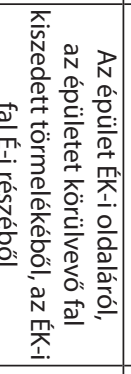 & 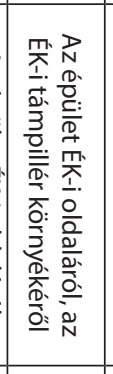 & $\sim$ & $\sim$ & 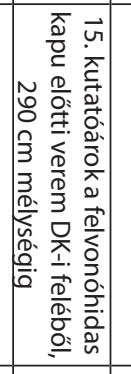 & 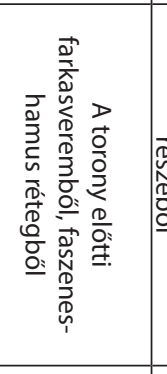 & 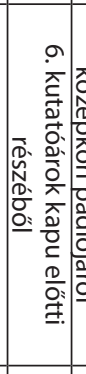 & 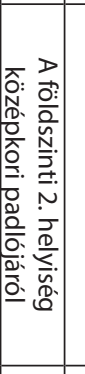 & 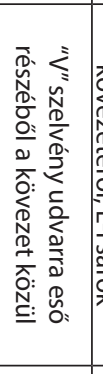 & 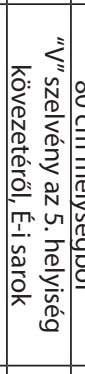 & 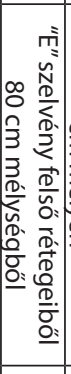 & 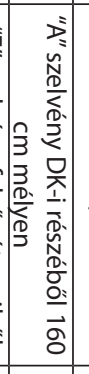 & 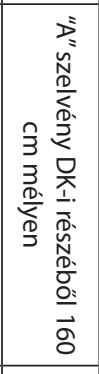 & 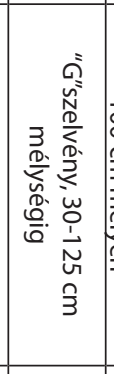 & 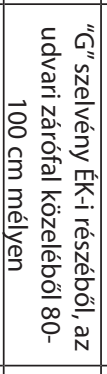 & 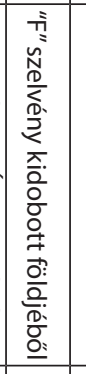 & 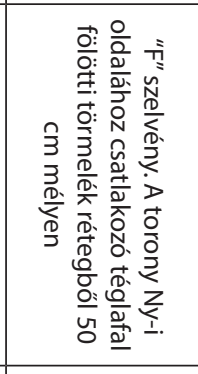 & 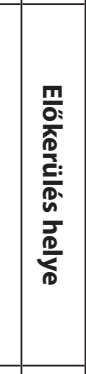 \\
\hline $\begin{array}{l}\vec{\circ} \\
.\end{array}$ & $\vec{\circ}$ & बे & $\vec{\circ}$ & $\begin{array}{l}\vec{\circ} \\
\stackrel{\circ}{\circ}\end{array}$ & ठठ & 悹 & $\begin{array}{l}\overrightarrow{0} \\
\text { o }\end{array}$ & 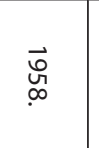 & $\overrightarrow{\stackrel{o}{v}}$ & $\begin{array}{l}\overrightarrow{0} \\
\stackrel{v}{.}\end{array}$ & 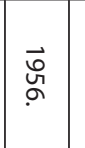 & 总 & $\overrightarrow{\text { v }}$ & $\overrightarrow{\stackrel{o}{v}}$ & $\overrightarrow{\stackrel{o}{v}}$ & $\overrightarrow{\stackrel{o}{v}}$ & 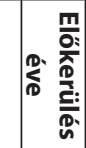 \\
\hline 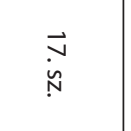 & $\begin{array}{l}\overrightarrow{\hat{T}} \\
\stackrel{\vec{N}}{\hat{N}}\end{array}$ & 晜 & $\begin{array}{l}\overrightarrow{\hat{i}} \\
\overrightarrow{\hat{N}} \\
\dot{N}\end{array}$ & $\begin{array}{l}\overrightarrow{\hat{i}} \\
\stackrel{\vec{N}}{\hat{N}} \\
\text { }\end{array}$ & $\underset{\grave{N}}{\vec{N}}$ & $\begin{array}{l}\overrightarrow{\hat{T}} \\
\stackrel{\vec{N}}{\hat{N}}\end{array}$ & $\begin{array}{l}\vec{a} \\
\dot{\grave{n}}\end{array}$ & $\begin{array}{l}\vec{\sigma} \\
\stackrel{\vec{v}}{\hat{N}}\end{array}$ & $\begin{array}{l}\overrightarrow{\hat{\sigma}} \\
\stackrel{\hat{n}}{N}\end{array}$ & $\begin{array}{l}\vec{v} \\
\dot{n}\end{array}$ & $\underset{\substack{\hat{N} \\
\grave{N}}}{\vec{N}}$ & 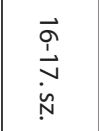 & $\begin{array}{l}\overrightarrow{\hat{Q}} \\
\stackrel{\vec{v}}{\hat{N}}\end{array}$ & $\begin{array}{l}\overrightarrow{\hat{O}} \\
\dot{\vec{N}} \\
\dot{n}\end{array}$ & 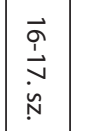 & $\underset{\grave{N}}{\vec{N}}$ & 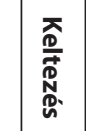 \\
\hline & & & & & 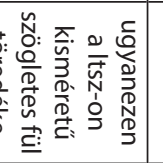 & & 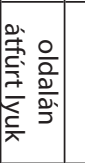 & & & & & & & & & & $\frac{a}{2}$ \\
\hline
\end{tabular}


1. 60.137 .4

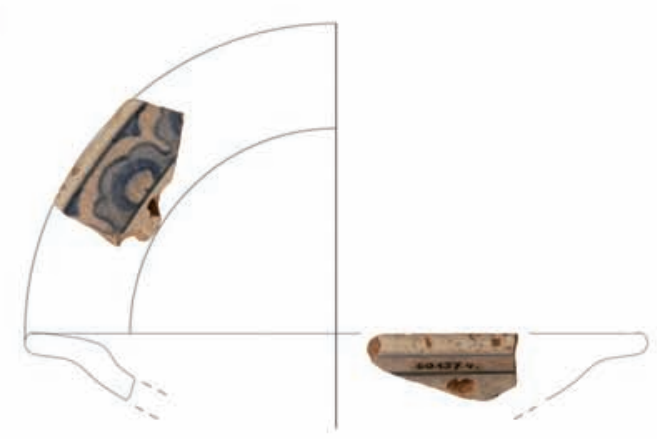

2. 60.125 .2

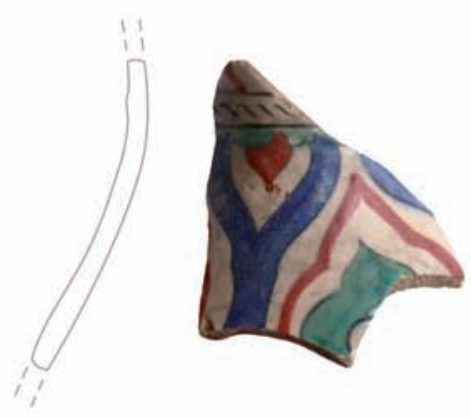

3. 59.11 .25

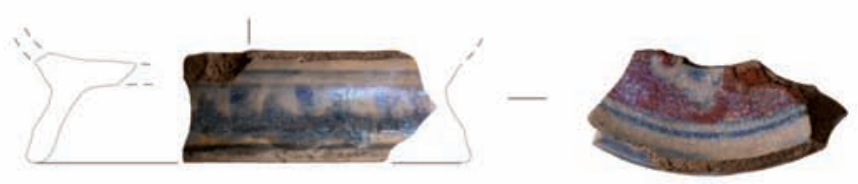

4. 60.127 .4

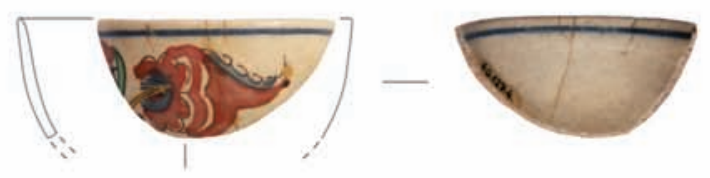

5. 63.50 .6
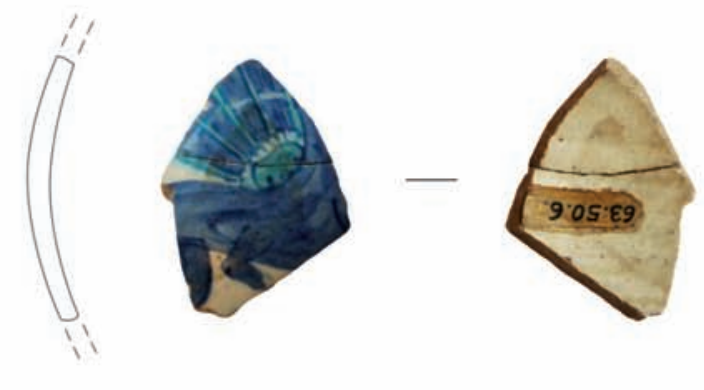

0

1. tábla: Izniki (és kütahyai) kerámia 
1. 63.119 .1
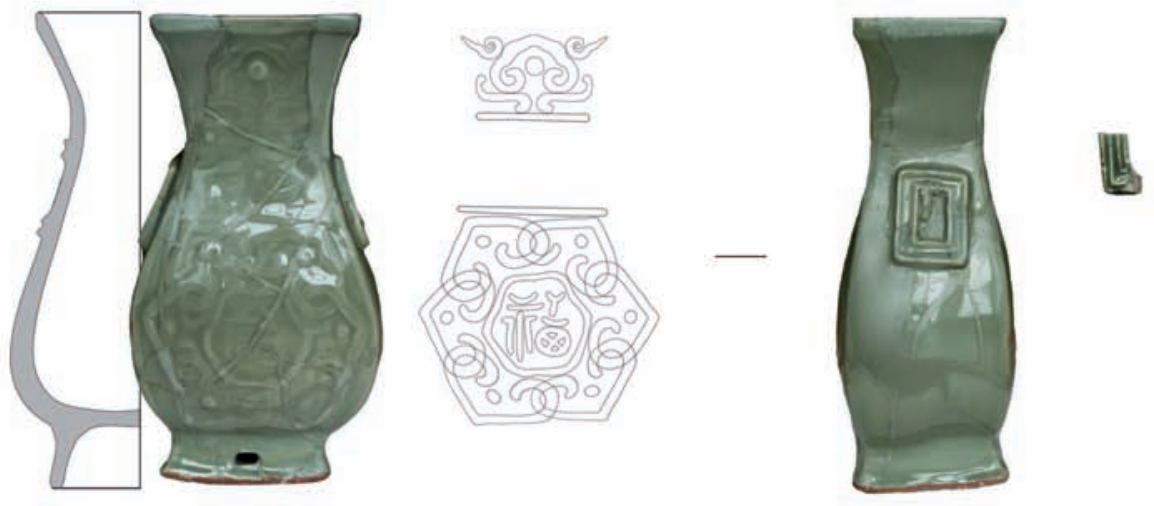

2. $59.5 .42 / 1$

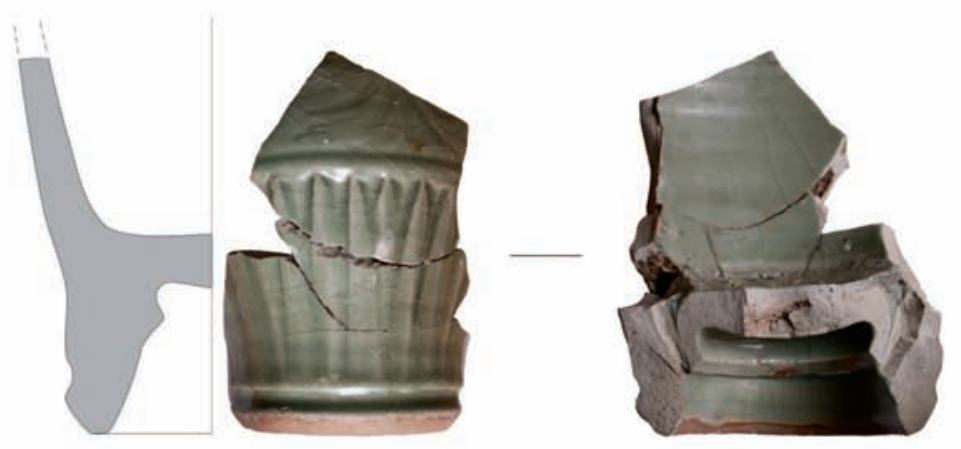

3. $59.5 .42 / 2$

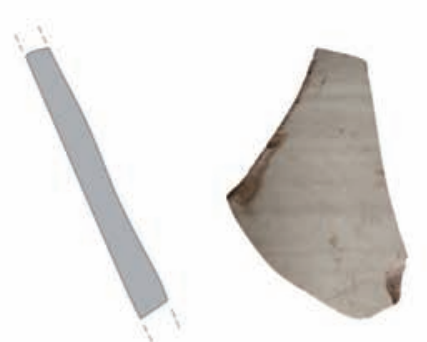


1. 59.9 .7
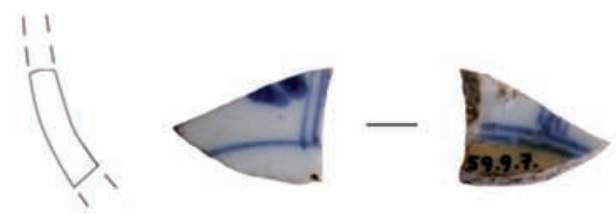

0 5

2. 59.10 .21

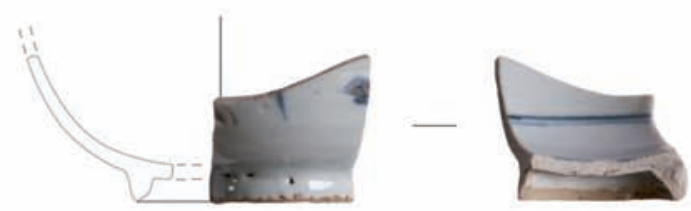

3. 59.11 .3

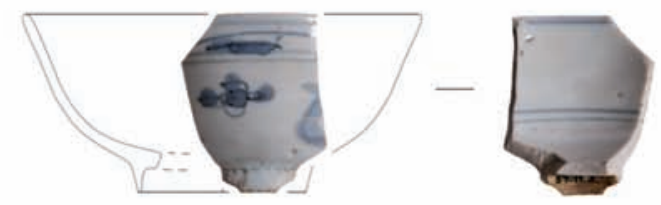

4. 60.157 .56

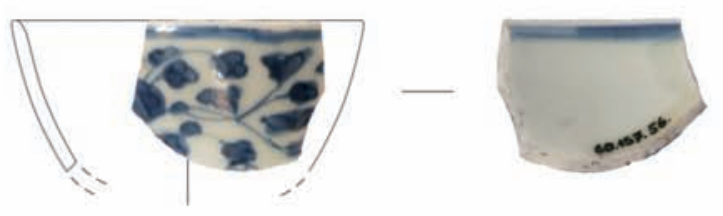

5. 63.85 .4
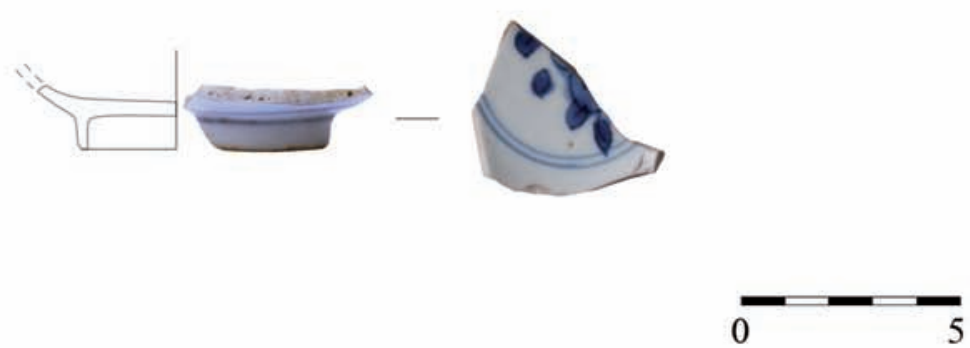
1. 59.10 .1

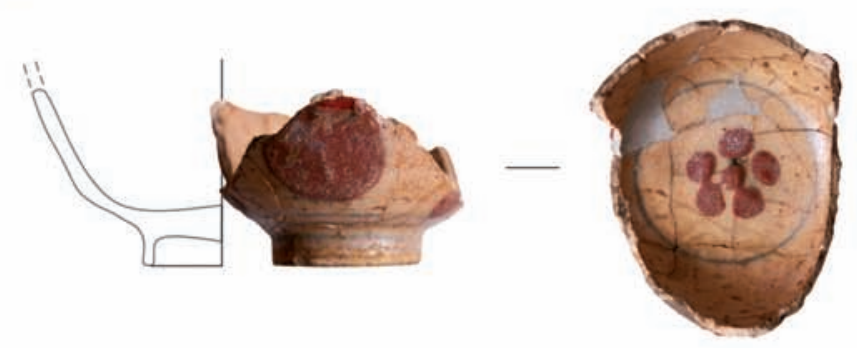

2. 63.15 .91

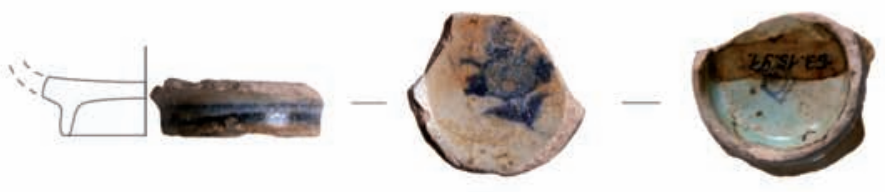

3. 63.51 .17

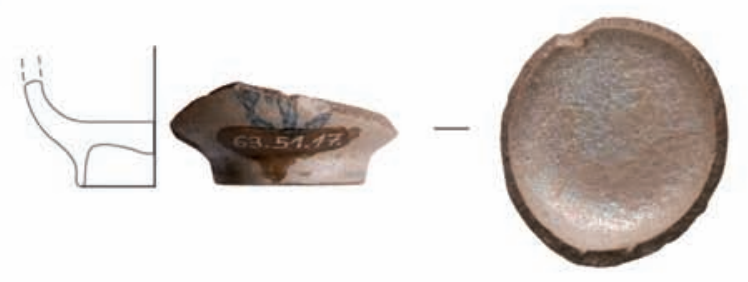

4. 63.76 .3
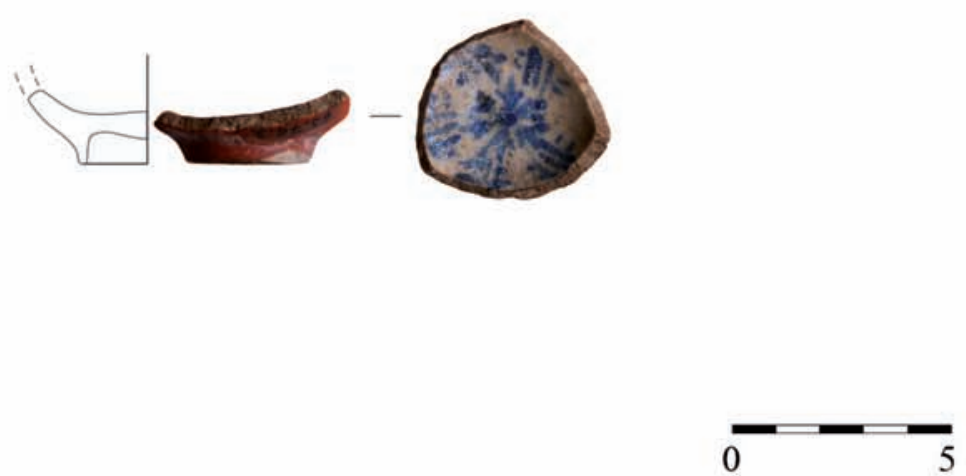

4. tábla: Perzsa fajanszok 


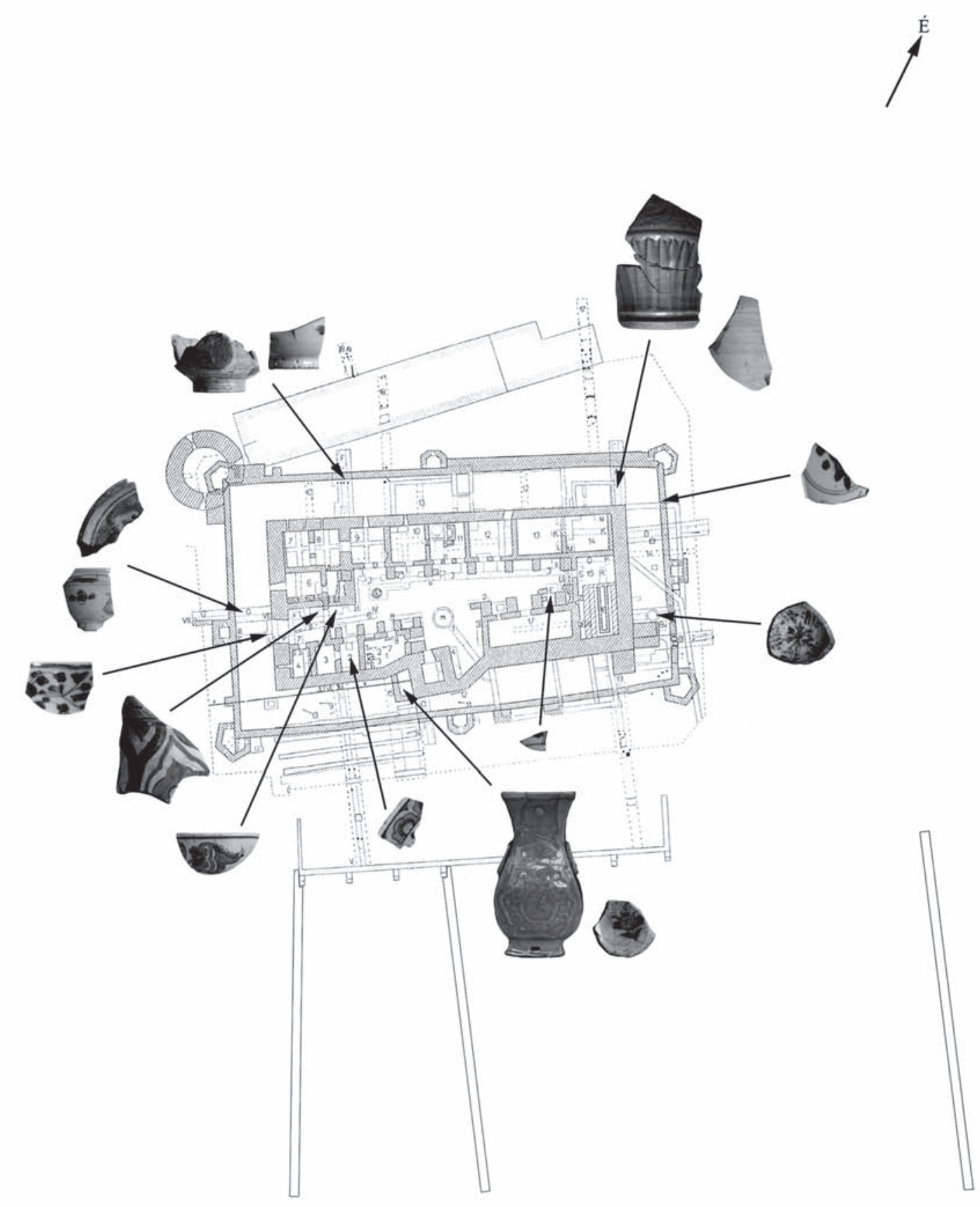

? 
